\title{
The Importance of Bioconservation and Biodiversity in Turkey
}

\author{
A. Kahraman, M. Onder, and E. Ceyhan
}

\begin{abstract}
Biodiversity represents the basis of all life on our planet or in a specific area. It is clear that natural resources do not last forever. Turkey is one of the most biologically diverse countries in the temperate zone. More than one third of species found in Turkey are endemic, native to the region. So Turkey is like a kind of small continent in terms of biodiversity. It is also rich as biodiversity with 120 mammals, 469 bird species, 130 reptiles, 400 fishes and 4000 endemic of 11000 plants species. However, this gene pool is threatened by genetic erosion as in some other parts of the world. The primary objective of germplasm conservation depends on genetic diversity. The importance of biodiversity is highlighted.
\end{abstract}

Index Terms-Diversity, environment, germplasm, species extinction, protection.

\section{INTRODUCTION}

The Earth is made up of ecosystems and ecological features which are supported by biodiversity; yet many people do not understand the meaning of biodiversity or what the impact of its loss would mean. The scarcity of non-renewable resources such as soils and fertilizers and the consequences of climate change can dramatically influence the food security of future generations [1]. Developing in agricultural production systems introduces the potential to provide a significant source of mitigation by increasing carbon stocks in terrestrial systems, with decreasing of emissions owing to increased efficiency [2]. Climate change, pollution and excessive use of resources in the last century cause to destruction of biological diversity and this situation is quite serious for human life. In order to highlight the importance of biodiversity, 2010 has been selected as the International Year of Biodiversity in an attempt to educate people on biodiversity and how biodiversity supports everyday life. The fact is that all the species of flora and fauna, including humans, are dependent on each other, and the extinction of any one of these species can trigger a domino effect on the other species, which are directly or indirectly dependent on it. Biodiversity covers the diversity of life on all these levels, the diversity within species, between species and the variability of habitats. Biodiversity in an ecosystem consisted from four main

Manuscript received January 1, 2012; revised February 29, 2012. This work was supported in part by the "Selcuk University, Coordinator of Scientific Research Projects" under project number 11701820. Some part of this article was presented as title of "Biodiversity and Biosecurity in Turkey" in Dubai-UAE, ICBEC 2011.

A. Kahraman, M. Onder, and E. Ceyhan are with Field Crops Department, University of Selcuk, Faculty of Agriculture, Konya, CO: 42075 TURKEY (corresponding author to provide phone: 009033222328 84; fax: 0090332 24101 08; e-mail: kahramanali@selcuk.edu.tr) sections: a) Genetic diversity b) Species diversity c) Ecosystem diversity d) Ecological processes diversity. Knowledge about the genetic characteristics of a population is fundamental in breeding programs and it involves the local farmers. This strategy allows improving and, at the same time, safeguarding the genetic reliability of landrace genetic resources [3]. Also, conservation or restoration of semi-natural habitats appears to be the most promising agro-environmental measure to enhance small mammal populations in intensified agricultural landscapes [4].

There is an increasing use of indicator taxa to predict spatial patterns in other taxa, yet it is unclear how well species from one taxonomic group may serve as indicators of species richness in other groups with different ecological needs [5]. Totally 12 countries includes 34 "hotspot" area that have 150000 endemic plant species $(50 \%$ of the world total). Although these areas once the world's $15.7 \%$ percent, $86 \%$ of the hotspot habitat being destroyed today and hotspot area declined to $2.5 \%$ percent [6]. In the recent years many developed countries completed determination of their plant and animal species and formed their relational species databases by benefiting geographical information technologies. These countries realized effective area managements and determined national development strategies on the subjects of determination, register and conservation of natural values. However, World-wide biological diversity on all levels is severely endangered. Through numerous factors such as changes of land use and habitat destruction are whole ecosystems (e.g. rainforests or coral reefs) and many species (e.g. Pandas) severely threatened. Conservation planning and management issues common to many important biodiversity sites throughout Turkey and providing models for replication in priority conservation areas in other parts of the country and the region, the studies will provide ecological, social, economic and institutional benefits at the global, regional, national and project site levels.

As the products that produced by modern biotechnology had a large extent usage in 1996, it brought some significant risks [7]. For this reason, in 1998, Turkey participated to preparatory work of Cartagena Protocol which was an additional protocol of Convention on Biological Diversity. In May 1998, the only legislation related to biosafety of transgenic plants which were Instructions for Field Trials was prepared.

Turkey is in the interface of three different biogeographically regions where consist from EuropeanSiberian, Mediterranean and Irano-Turanian regions. Back to approximately 10000 years from now is the date of settlement and starting of relations between human and plants 
in Turkey. So, this country is a region where firstly agricultural practices were made for many natural spread plants. Seed propagation and long-term human selection has also given rise to a great diversity of trees. Local populations are also important to have gene pool. Also pumpkin genotypes that collected from different parts of
Turkey showed quite differences [8]. However, this gene pool is threatened by genetic erosion [9]. Though limited to about $26 \%$ of the total land area of the country, maintaining healthy forests is vital to support sustainable development in Turkey [10].

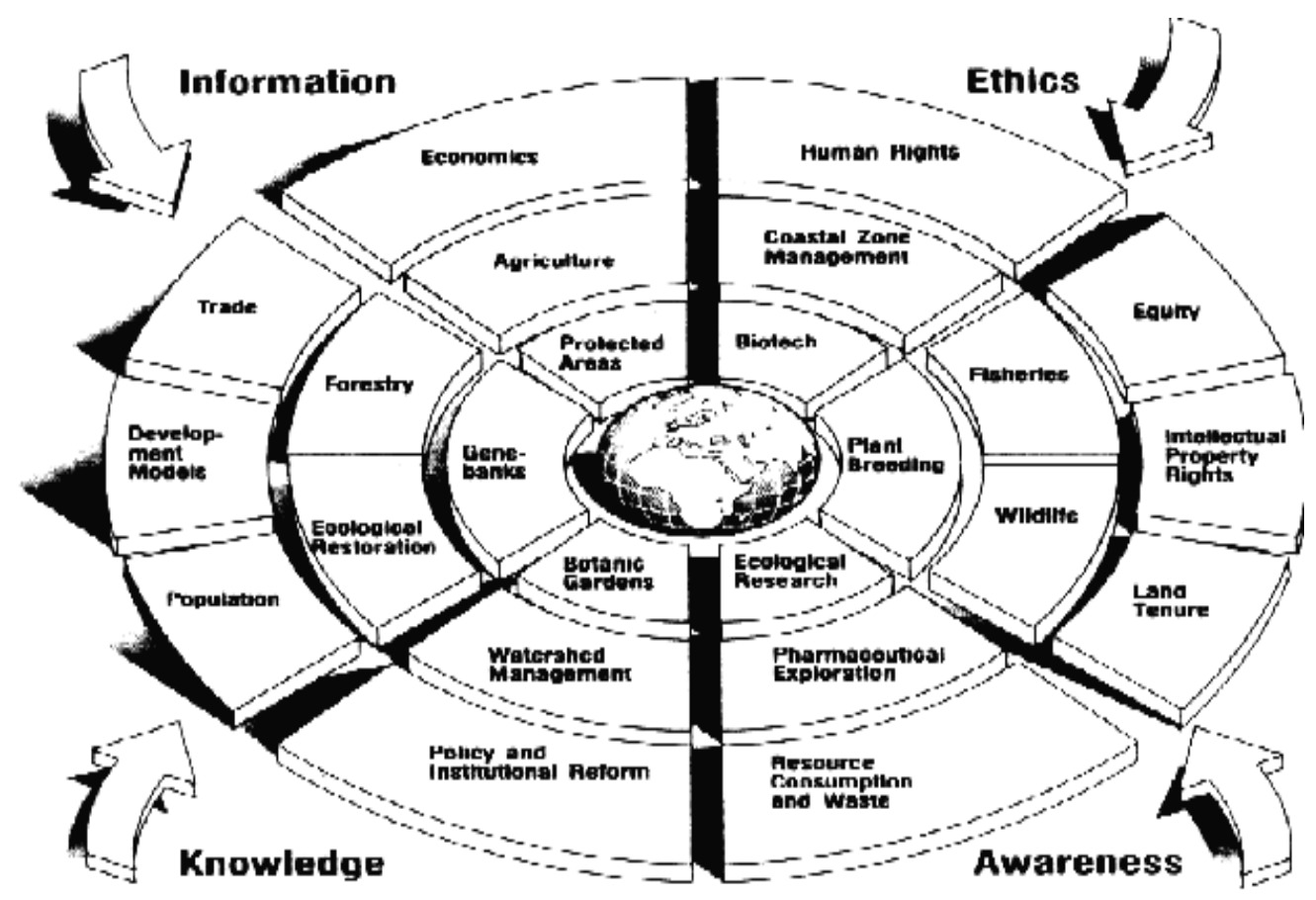

Fig. 1. A model of biodiversity and its relations.

Fig. 1 shows a concept model for biodiversity and bioconservation [11]. As it seen in Figure 1, biodiversity is a multidisciplinary system.

It is well known that the quantity of air and water pollution, environmental disasters, forest destroying and harmful waste is increasing. It is quite hard to see daily changes. But, all the things which are affecting the environment would be dangerous eventually. When we try to resolve those problems, it is going to need long time, a lot of money, huge energy and recovery of the all organisms which had been destroyed. Today, it is possible to mention about biodiversity loss approximately on crisis levels in many parts of the world. There are many species which are in danger. The objective of this article is to emphasize the importance of biodiversity and making some suggestions to conserve it for next generations with an example model on Turkey.

\section{BIODIVERSITY, BIOCONSERVATION AND TURKEY}

\section{A. Importance of Biodiversity}

World Health Organization (WHO) estimates that $60 \%$ of people depend on plants as general health status. Human has been used diversity for many years for almost all the things that they need. Around 80000 wild plant species consumed by humans. More than half of medicines that prescribed by doctors contain natural products. Soil formation, waste control, air and water clean, the food cycle, the solar energy absorption, and hydrological cycles are all depend on biodiversity and estimated annual cost of approximately
\$33 trillions.

Cultural diversity inevitably depends on biological diversity. Also, biodiversity is thought to be a form of sustainable economic development of ecotourism. Documenting the basic patterns of biodiversity and accurately determining the priority areas are the first steps for conservation studies [12].

\section{B. Biodiversity in Turkey}

Anatolia is a geographic and historical term denoting the westernmost protrusion of Asia, comprising the majority of the Republic of Turkey. Although Anatolia is not a separate continent in itself; it is like a small continent that has the exclusive properties of the whole ecosystem and habitat. The country is one of the richest countries between Europe and the Middle East in terms of biodiversity. Turkey has $33 \%$ endemic species of totally 9000 plant species. The reason of rich biodiversity in Turkey is climatic differences, geological and geomorphologic diversity, sea, stream, lake etc. mediums, and elevation varieties. It has various kinds of topographical, soil variations, fresh, salty and alkaline water types. Each of 7 geographical climates of the country is different, and has a diversity of flora and fauna. Anatolia is extremely rich with over 80000 types in fauna and its contents 4000 endemic of 19000 invertebrates, 123 endemic of 1500 vertebrates [13]. One of the three major flyways for migratory birds passes through Turkey. Turkey is one of the most important biodiversity centers in the world with more than $30 \%$ endemics out of nearly 12000 natural vascular plant taxa. For example, nearly $30 \%$ of field crops are known 
as Anatolian origin. Anatolian is origin of the wheat. Wheat that is a basic food for human nutrition, wild relatives is the focus of interest for researchers because of resistance genes to diseases, drought and salinity. A single gene is expressed in millions of dollars. Another example, saffron shows a narrow spreading over an area in Turkey and, saffron is the most expensive spice of the world compared to weight. Anatolia is also origin many kinds of valuable species like tulips. Among the aromatic taxa, remarkable examples can be found in families such as Labiatae, Compositae, Umbelliferae, etc [14]. Although there are more than 1.000 varieties of grapes in Turkey, only 60 varieties of them are economically grown [15]. It is certain that eight of endemic plant species disappeared in $19^{\text {th }}$ and $20^{\text {th }}$ centuries [16].

\section{Threats to Biodiversity}

We can summarize the reasons as over-grazing of meadow and grassland, erosion, stubble burning, agricultural practices by machine, irregular and excessive use of pesticides in agriculture, drying of wetlands, dams, urbanization, industrialization, household and industrial waste, global warming, excessive hunting and collection. Changing of climate affects by affecting vegetation and weather relevance. For instance, a tree which flowers at a different time on the calendar affects the insects that carry pollen, and changing of the insect populations also affects the feeding opportunities for birds and reptiles. Changing of weather increases the intensity and frequency of storms or the violence of heat waves and drought also affect the health of species and their resistance to diseases and pesticides.

\section{Bioconservation and Protection Works}

There are several protection areas in Turkey for in-situ and ex-situ. If we look at for the in-situ protection facilities; there are 39 national parks, 32 nature conservation areas, 22 nature parks, 104 natural monuments, 80 wildlife development areas, 14 special environmental protection areas, 1000 natural sites, gene conservation and management areas (Bolkar, Ceylanpinar), 12 wetlands of international importance. There are also many areas for ex-situ protection like national gene bank (was established in 1972, has 600 genus spread on 50000 materials), field gene banks (consists from 16 research institutes and mainly collect fruit species), Osman Tosun Gene Bank (has 11000 seeds samples), seed gardens, seed plantations, clone parks. And, 350.000 line biodiversity data take place in the date base as of today [12]. Biodiversity agreement entered into force in Turkey 14 May 1997. The target of the agreement is able to protect biological diversity with using biological resources a nd genetic resources in a sustainable manner, and saving these resources for economy until 2018 can summarize the reasons as over-grazing of meadow and grassland, erosion, stubble burning, agricultural practices by machine, Irregular and excessive use of pesticides in agriculture, drying of wetlands, dams, urbanization, industrialization, household and industrial waste, global warming, excessive hunting and collection.

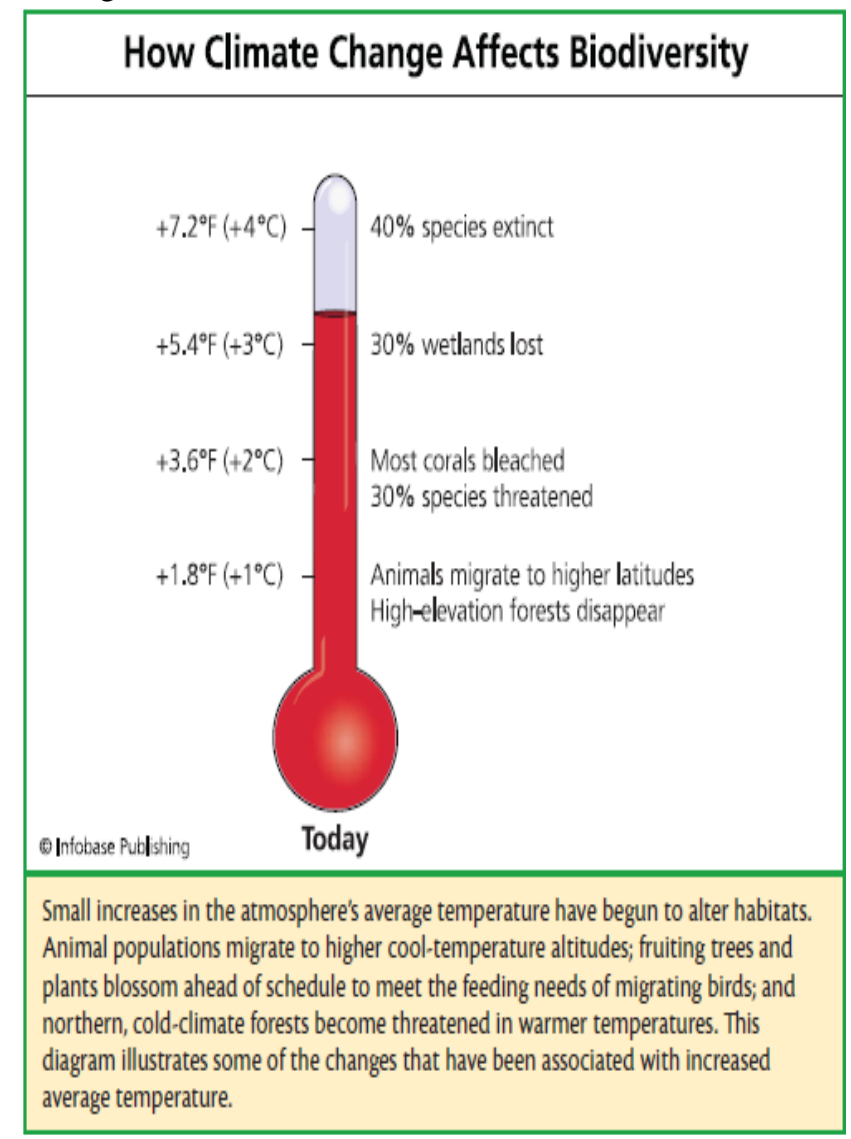

Fig. 2. Effects of climate on biodiversity

Fig. 2 shows the affects of climate change on biodiversity [17].

\section{CONCLUSION}

The reason of desertification in Turkey is generally caused by incorrect land use, excessive grazing, forest fires, urbanization, industry, genetic erosion, soil erosion, salinisation, and uncontrolled wild type plants collecting [18]. With special qualifications in the area of plant diversity in Anatolia, the vegetation is described in the scientific sense with a new species with each passing day and the number of these plants is very high. The protection of the diversity has great importance in Turkey. Urban landscape includes constantly dynamic changing. Therefore, in putting forward this changing the plants are important indicator living materials [19]. For example, of 3504 endemic plants in Turkey, 12 are known to have been extinct and 3492 (99\%) are still being threatened [20]. Every single year, approximately 8000-10000 species get lost in the world [21]. Urban planning can serve as an effective instrument to reduce the adverse impacts of urbanization on natural environment [22]. Everyone should take certain tasks and fulfill the task more for determination, conservation and sustainable usage of biological diversity. Non-governmental organizations should be supported to encourage the urbanites to act in an organized way to solve forestry problems [23]. If diversity-enhancing measures should benefit non-farmland populations, it is likely that they do not favor farmland specialist species which are more at risk [24]. Positive 
environmental impacts resulted from recycling, forest industry products and use of energy [25]. Bio-screening effort should strictly adhere to the precepts of the Convention of Biological Diversity [26]. If there is no continuing non-stop various natural interactions between living organisms and lifeless' or within living organisms in the ecosystem; the living organisms in there doomed to disappear within a few generations. Also, if there isn't any genetic diversity within a species, it would lose within a few generations. For this reason humanity developed a new perspective to decrease the negative effects of agriculture. Sustainable agriculture which is a new agricultural technique seems environmentally friendly and it is supported by developed countries. Environmentally friendly agriculture has three common applications as good agricultural practices, organic agriculture and precision agriculture. Also rotation, sowing of legumes that able to nitrogen fixation and fallowing reduce the negative effect of agriculture on climate change.

As we know, water and air are the abandonment sources of agriculture and all vital activities. Also plants are the most important source that feeding necessity of the human population who increase rapidly [27]. It is well known that one of the most important reasons for protecting and/or supporting natural biodiversity is that it satisfies a kind of ecological services [28]. The vegetation of forest or grassland prevents soil erosion, restocks groundwater, controls flooding by increasing infiltration and decreasing water flowing. Similar way, biodiversity also serves ecosystem services on the other side fuel, food, fiber, and income production. These are such as recycling of nutrients, control of local microclimate, regulation of local hydrological processes, regulation of the abundance of undesirable organisms, and detoxification of noxious chemicals. That kind of renewable processes and ecosystem services are generally biological, so their permanency depends on keeping of biological diversity [29]. In developing economies particularly where there aren't any oil and natural gas reserves, the most important source of natural wealth is agricultural land. In these places, using the lands for agriculture is increasing rapidly through conversion of forests, wetlands and other natural habitat [30]. These kinds of implementations include some examples such as: i) water diversions for irrigation, industrial or domestic usage reduces in-stream flows which support to existence of various fish populations. ii) reclamation of swamps and wetlands which serve as habitat for local plant, bird and animal populations. iii) deforestation reduces the living territory of many kinds of species. iv) conscious pesticide usage will support the natural predators. v) regular grazing promotes soil fertility and prevents erosion and/or desertification. vi) airborne industrial pollution cause to acid rain and it interferes with freshwater ecosystems $[31,32]$. As Earth's climate changes, the roles of species and ecosystems will only increase in their importance to humanity [33]. In addition to cost for potential synergies between food security, adaptation and relief chances, it can really differ across agro-ecological zones, climate regimes, and historical land use models [34]. If we compare to the problem of biodiversity and climate change, it is possible to say: biodiversity problem is worse than climate change.
Extinction of species and the degradation of ecosystems are increasing. The world is losing at a rate from 100 to 1000 times faster than the natural extinction rate [35].

Human needs to know more for the purpose of living better. As a result of the more we study about environment, the quality of life will be more. Some effects of the implementations that mentioned above may not directly influence to human, but there are many risks as indirectly doubtless. It is certain that; any damage on biodiversity would cause to harm for today or future in the long run and, human is the main reason about do damage on the environment. Even if we are able to recover just one of lost biological services, the price to regain it will require quite expensive cost and also needs too much time. Environment that comprised by unpolluted air, water, soil, far from noise and other dirtiness, clean, beautiful, green and healthy is the biggest demand of present day human and guarantee of future. We need to develop new technologies which are property of green technology and, also determinate and protect the habitat and adaptation abilities of all living organisms.

We have to notice: The future of life depends on us.

\section{REFERENCES}

[1] P. Mäder, F. Kaiser, A. Adholeya, R. Singh, H. S. Uppal, A. K. Sharma, R. Srivastava, V. Sahai, M. Aragno, A. Wiemken, B. N. Johri, and P. M. Fried. Inoculation of root microorganisms for sustainable wheat-rice and wheat-black gram rotations in India. Soil Biology and Biochemistry, vol. 43, pp. 609-619, 2011

[2] W. Mann, L. Lipper, T. Tennikeit, N. McCarthy, and G. Branca. Food Security and Agricultural Mitigation in Developing Countries: Options for Capturing Synergies. Food and Agriculture Organization of the United Nations (FAO). Rome, Italy, 2009.

[3] A. Kahraman and Önder, M. Genetic Diversity in the Dwarf Dry Bean (Phaseolus vulgaris L.) Populations Grown in Konya. $1^{\text {st }}$ International Syposium on Sustnable Devel. 2009, vol. 3, no. 8-10, pp. 13-19, Sarajevo-Bosnia.

[4] C. Fischer, C. Thies, and T. Tscharntke. Small mammals in agricultural landscapes: Opposing responses to farming practices and landscape complexity. Biological Conservation, vol. 144, pp. 1130-1136, 2011.

[5] S. Fattorini, R. L.H. Dennis, and L. M. Cook. Conserving organisms over large regions requires multi-taxa indicators: One taxon's diversity-vacant area is another taxon's diversity zone. Biological Conservation., vol. 144, pp. 1690-1701, 2011.

[6] A. D. Atik, M. Öztekin, and F. Erkoç. Biodiversity and examples of endemic plants in Türkiye. G̈̈, Gazi Eğitim Fakültesi Dergisi. 2010, Cilt 30, Sayı 1 pp. 219-240.

[7] M. Baran and F. Özçelik. Biyogüvenlik ve Türkiye'de uygulanabilme düzeyi. Türkiye 9. Gida Kongresi. 2006, Bolu.

[8] M. Seymen, O. Turkmen, and M. Paksoy. Secilmis cerezlik kabak (Cucurbita pepo L.) genotiplerinin bazi bitkisel ozellikleri. Türkiye IV. Tohumculuk Kongresi. 2011, Cilt 1, pp. 228-235.

[9] U. Yilmaz, Y. Zengin, S. Ercisli, E. Orhan, E. Yalcinkaya, O.Taner, and A. Erdogan. Biodiversity, ex-situ conservation and characterization of cornelian cherry (Cornus mas L.) genotypes in Turkey. Biodiversity and Ecosystems. 2009, pp. 1143-1149.

[10] Z. Kaya and D. J. Raynal. Biodiversity and conservation of Turkish forests. Biol. Conservation. 2001, vol. 97, pp. 131-141.

[11] Anonymous, http://www.aaas.org/international/ehn/biod/ness1.htm

2012

[12] C. Ture and H. Bocuk. Distribution patterns of threatened endemic plants in Turkey: A quantitative approach for conservation. Journal for Nature Conservation. 2010, vol. 18, pp. 296-303.

[13] Anonymous, 2012. www.cevreorman.gov.tr

[14] K. Hüsnü and C. Baser. Aromatic biodiversity among the flowering plant taxa of Turkey. Pure Appl. Chem. 2002, vol. 74, No. 4, pp. $527-545$.

[15] I. Uzun and A. Bayir. Horticultural biodiversity in Turkey. Bulletin UASVM Horticulture. 2009, vol. 66, no. 2, pp. 536-543.

[16] Turkish Ministry of Environment. Ulusal Biyolojik Çeşitlilik Stratejisi ve Eylem Planı. 2001, Ankara, Turkey. 
[17] A. Maczulak. Biodiversity: Conserving endangered species. Green Technology. Facts on File. 2010, New York.

[18] S. C. Cetin, A. Karaca, K. Haktanir, and H. Yildiz. Global attention to Turkey due to desertification. Environ Monit Assess. 2007, vol. 128, pp. 489-493.

[19] C. Acar, H. Acar, and E. Eroglu. Evaluation of ornamental plant resources to urban biodiversity and cultural changing: A case study of residential landscapes in Trabzon city (Turkey). Building and Environment. 2007, vol. 42, pp. 218-229.

[20] Z. Bulut and H. Yilmaz. the current situation of threatened endemic flora in Turkey: Kemaliye (Erzincan) case. Pak. J. Bot. 2010, vol. 42, no. 2, pp. 711-719.

[21] M. Dogan. Türkiye'de biyolojik çeşitliliğin korunması. Türkiye'de Biyoçeşitlilik ve Organik Tarım Çalş̦tay Raporu. 15-16 Nisan 2003, 139. Dedicated to the: Agenda 21. Programme of Action for Sustainable Development. 1992, UN Publ. New York.

[22] J. A. Puppim de Oliveira, O. Balaban, C.N.H. Doll, R. Moreno-Peñaranda, A. Gasparatos, D. Iossifova, and A. Suwa. Cities and biodiversity: Perspectives and governance challenges for implementing the convention on biological diversity (CBD) at the city level. Biological Conservation. 2011, vol. 144, pp. 1302-1313.

[23] E. Atmis, S. Ozden, and W. Lise. Urbanization pressures on the natural forests in Turkey: An overview. Urban Forestry and Urban Greening. 2007, vol. 6, pp. 83-92.

[24] M. Koskela. Expert views on environmental impacts and their measurement in the forest industry. Journal of Cleaner Production. 2011, vol. 19, pp. 1365-1376.

[25] O. F. Codaccioni, V. Devictor, Y. Bas, J. Clobert, and R. Julliard. O. F. Codaccioni, V. Devictor, Y. Bas, J. Clobert, and R. Julliard. Specialist response to proportion of arable land and pesticide input in agricultural landscapes. Biological Conservation. 2010, vol. 143, pp. 883-890.

[26] C. H. S. Lagoudakis, E. M. Williamson, V. Savolainen, and J. A. Hawkins. C. H. S. Lagoudakis, E. M. Williamson, V. Savolainen, and J
A. Hawkins. Cross-cultural comparison of three medicinal floras and implications for bioprospecting strategies. Journal of Ethnopharmacology. 2011 vol. 135, pp. 476-487.

[27] A. Kahraman and M. Önder. Drought and its physiological effects on plants. $10^{\text {th }}$ International Multidisciplinary GeoConference SGEM 2010, Conference Proceedings, Volume II, Page 515-519, $20-26$ June, Bulgaria.

[28] M. A. Altieri. Patterns of insect diversity in monocultures and policultures of brussel sprouts. Prot. Ecol. 1991, vol. 6, pp. 227-232.

[29] M. A. Altieri. Agroecology: The science of sustainable agriculture. Westview Press. 1995, Boulder, CO.

[30] E. B. Barbier. Natural resources and economic development Cambridge University Press. 2005, Cambridge.

[31] C. Bird. Medicines from the forest. New Scientist. 1991, vol. 17, pp. 34-39.

[32] R. Littell. Endangered and other protected species: Federal law and regulations. The Bureau of National Affairs Inc. 1992, Washington, DC.

[33] W. R. Turner, M. Oppenheimer, and D. S. Wilcove. A force to fight with global warming. Nature. 2009, 462:278-279G. O. Young, "Synthetic structure of industrial plastics (Book style with paper title and editor)," in Plastics, 2nd ed. vol. 3, J. Peters, Ed. New York: McGraw-Hill, 1964, pp. 15-64.

[34] N. McCarty, L. Lipper, and G. Branca. Climate-Smart Agriculture: Smallholder Adoption and Implications for Climate Change Adaptation and Mitigation. Food and Agricultural Organization of the United Nations (FAO). 2011, Mitigation of Climate Change in Agriculture Series 4.

[35] University of Copenhagen (2012, January 20). Biodiversity crisis is worse than climate change, experts say. ScienceDaily. Retrieved February 18, 2012, from http://www.sciencedaily.com/releases/2012/01/120120010357.htm 